\title{
Anabases
}

ANABASES Traditions et réceptions de l'Antiquité

$20 \mid 2014$

Varia

\section{English Translations of Homeric Epic in Dactylic Hexameters}

\section{Rodney Merrill}

\section{(2) OpenEdition}

1 Journals

Édition électronique

URL : https://journals.openedition.org/anabases/4922

DOI : $10.4000 /$ anabases.4922

ISSN : 2256-9421

\section{Éditeur}

E.R.A.S.M.E.

\section{Édition imprimée}

Date de publication : 1 novembre 2014

Pagination : 101-110

ISSN : 1774-4296

\section{Référence électronique}

Rodney Merrill, «English Translations of Homeric Epic in Dactylic Hexameters », Anabases [En ligne], 20 | 2014, mis en ligne le 01 novembre 2017, consulté le 15 février 2023. URL : http:// journals.openedition.org/anabases/4922 ; DOI : https://doi.org/10.4000/anabases.4922

\section{(c) (i) () $\Theta$}

Creative Commons - Attribution - Pas d'Utilisation Commerciale - Pas de Modification 4.0 International - CC BY-NC-ND 4.0

https://creativecommons.org/licenses/by-nc-nd/4.0/ 


\title{
English Translations of Homeric Epic in Dactylic Hexameters
}

Rodney MerriLl

\begin{abstract}
Mênin áeide, theá, Peleïádeo Achilêos
ouloménen, hè murí Achaioîs álge' étheke, pollàs d'iphthimous psychàs Ä̈di proíapsen, heróon, autoùs de helória teûche kúnessin, oionoîsi te daîta, Diòs d'eteleieto boulé, ex hoû dè ta prôta diastéten erísante Atreídes te ánax andrôn kaì dîos Achilleús.
\end{abstract}

This as an invocation addressed to the spirit of Homer, may it be present among us on this auspicious occasion. Next is my heartfelt thanks to Professor Brunet and the others who have devised this great celebration of epic and drama from which we will return to our homes entertained and enlightened thanks for inviting me here to discourse on a subject I cherish. This is a task I approach with great satisfaction, because I started to read the original Iliad only in Paris when as a student at Stanford I came to investigate early Renaissance lyrics of France, of Clément Marot and his fellows. Many an hour on the Iliad's first few books did I ponder, teaching myself new words by making a list with the meanings. So I remain most grateful to France and its people for giving me that gift of those months of development, freedom, and pleasure. 
Perhaps like Others among Us, I came to my long project of translation less from a sense of duty than from a love of the Homeric epic and of the music that gives it such vivid life. Just as I can participate in the musical genius of a Bach or a Debussy by playing his music on the keyboard, so I can claim an active share in the Homeric music by working out its rhythms in English. The prospect of such satisfaction made me take up translating the Odyssey in 1975. Having left my position as Assistant Professor of English at Berkeley, I traveled to Lisbon with my partner, who was born in the island of Madeira and wanted to experience metropolitan Portuguese life. It was the year of the retornados from Portugal's newly liberated African domains, and we could not find accommodations in the crowded city. So we kept living in a rusty Volkswagen bus converted into a rudimentary camping van in the Parque de Campismo through a cold and rainy winter. And I had no feeling that I should do something more responsible than translating the Odyssey into dactylic hexameters. I chose the Odyssey because like most amateurs I found it the more approachable of the two great epics. Day after day I sat in the driver's seat working out my version of the hexameter. I liked it so much that I kept on doing it when I returned to Berkeley, even after I had to face financial facts and get part-time jobs teaching English composition to support myself. That sheer enjoyment never vanished from the enterprise, which went on for twenty-five years until the work was published.

Yet as with you others, doubtless, some sense that I could do a service to my culture and society also motivated me, that those who cannot learn ancient Greek are deprived of the musical experience of the Homeric epic, and that such deprivation could to some extent be remedied by a careful and informed effort to bring the music into the modern language. This feeling may have been especially strong in my case, as I grew up in a place -Idaho Falls, Idaho, in the western United States- where ancient Greek culture was not much heard of. I encountered Homer and Greek tragedy in the local public library, not in school. I don't blame my teachers; the prevailing culture was simply not interested in such antiquities. So I have been highly conscious of the need to give as lively as possible a representation of that ancient culture, one that requires little or no initiation into the mystique, if I may so term it, of classical studies.

Even so, that Idaho childhood gave me some priceless formative experiences. The piano lessons my parents started me on at seven years old, at the hands of a strict and skillful teacher, both sharpened my musical sense and made me aware that good music emerges from a close and laborious attention to the details of execution. When I was 13 years old, my English teacher introduced me to Henry Wadsworth Longfellow's dactylic-hexameter narratives drawn from American history, Evangeline and The Courtship of Miles Standish, then considered American classics but now quite out of fashion. Whatever their poetic merits, they implanted the rhythm in my young mind and probably made it responsive to the great Homeric music when I encountered it. Perhaps my sense of duty was reinforced by a latent feeling that the task might be accomplished, despite dubious earlier attempts at such translations and deep skepticism among anglophone scholars and critics. 
This fragment of autobiography can illuminate my approach to these projects by underlining that in terms of preparation I am an amateur in both senses of the word. That is, my highly motivating love of the work has made me pursue it for over three decades, despite doubts and distractions. But I do not have the education of a scholar in the classical languages that my colleagues here have. I have read widely in the literature on Homer and the hexameter, have even sat in a seminar with Gregory Nagy, a distinguished Homerist. And I have made good use of the scholarship of others, as embodied, for example, in the multi-volume Cambridge and Oxford commentaries on the two epics. I have profited greatly from the advice of professional colleagues, Thomas Walsh on my Odyssey translation, J. K. Anderson and Stephen Daitz on my Iliad translation. But I cannot claim the deep erudition in classical and philological studies of scholars like Professor García Calvo.

On the other hand, I have an education in the literature of modern languages which has proved useful to a translator of formal poetry like the epic: as a student at Harvard College and then at Stanford University, I studied some of the greatest formal poetry in English by Chaucer, Spenser, Shakespeare, and Milton and others. Later as a teacher at Berkeley I taught many of them. Thereby I learned how English syntax is flexible enough to bring to poetic verse a force and variety often impossible with "normal" syntax. This understanding was reinforced as I became acquainted with the major Italian and French poets - Dante, Petrarca, Corneille, Racine, Molière. My translations bear the mark of that training: most recent English translations of Homer follow the reigning orthodoxy of "natural diction and syntax" in maintaining normal colloquial English word-order. By doing so, I believe, they often misrepresent the artifice of Homer, whose directness and speed depend not on colloquialism but on a special art-language, a "Kunstsprache," and an artful organization of language as used in song. With the splendors of Spenser and Milton in my mind, I would not submit to any dogma -e.g., avoidance of inversion of the "normal" subject-verb order- that would prevent extending the range of English syntax. It would also make difficult the falling rhythm of dactylic verse, as most English sentences and phrases begin with a weak syllable.

For above all, it was the dactylic music of Homeric epic that attracted me. I had long been interested in the connections between words and music; I wrote a Harvard honors thesis on the poetry of Sir Thomas Wyatt, writer of lute-songs, a major figure in the song-tradition that English poets like Chaucer received in large part from the great flowering of the French lyric of courtly love. My Stanford doctoral dissertation concerned the formal elements of that late medieval tradition itself, in England and France, with much attention to the lyrics in formes fixes of Charles d'Orléans. Therefore, as my acquaintance with Homeric epic grew, I became increasingly aware that its strict yet flexible meter is no mere decoration, no mere remnant of the work's origin in bardic song, but essential to its meaning and to the experience of the oral epic. And I learned that the figure of the aoidos portrayed in the Odyssey-Phemios in Book 1, Demodokos in Book 8- was given new substance by the researches of another 
American in France, Milman Parry, student of Antoine Meillet, and Alfred Lord and their successors, in the South Slavic epic tradition. This singer, in ancient Greece or recent Yugoslavia, is a man who accumulates in a receptive mind from early youth a huge stock of formulae, themes, and tales, and who can draw from that stock in singing a tale for a specific audience and occasion, either a single episode, several episodes, or a whole history. Though he professes to convey the song as he received it, in fact he varies it according to the social context, whether party, wedding, coffee house gathering, or American scholars seeking to transcribe all he knows. I hardly need to enlarge on this subject to such a group. As I became better acquainted with this view of "composition in performance," it shaped my understanding of my task, making me bring out the formulas and other repeated elements.

Despite my veneration for the great Singer whom we call Homer, and who was probably unable to read or write, I have taken as my point of departure the standard texts, which attained nearly their present state in Alexandria two centuries or so before the Common Era. These texts present us highly finished artifacts, and Professor Brunet has shown such significant parallels between the two epics as to make it likely that they were both masterworks of that great singer. However, when I am presenting my translations to an audience, I imagine myself neither as a pre-literate singer nor as an Alexandrian reader, but as a rhapsode who might have participated in the relay-recitation of the Homeric poems at the Greater Panathenaic Festivals in Athens. Plato presents such a rhapsode, Ion, in his eponymous Socratic dialogue: he seeks to give vivid dramatic life to what he is reciting or chanting rather than singing, in our sense, so as to move the audience to tears or fear or laughter. He, like me, had a fixed, authoritative, and venerated text, and he had neither the freedom nor the ability to change it. The authority was justified by the transcendent genius of the work that he knew by heart. Some may think the premise of my translation-work excessively reverential of the received text, but as a non-scholar I take it simply as given. This is not to belittle textual scholarship: if I had known Prof. Ventre's magisterial discussion of a variant in the proem, instead of "pasi" I would have read and translated "daita," which I adopted in my "invocation," "oionoisi te daita." Of course, even with the most painstaking care, no translation however faithful or musical can possess the authority of the text. Still, I tried to represent the Homeric epics as closely as I could.

The melodic component of Homeric song is lost, though perhaps the pitchaccents inserted into the text by the Alexandrian scholars preserve some record of it. Instructed by Prof. Stephen Daitz's efforts to revive the authentic pronunciation of ancient Greek, I tried to say the Proem of the Iliad with that sort of intonation. But even if these accents point to a melodic setting, I cannot translate them. The rhythmical component of the music, on the other hand, is preserved with considerable precision in the written text we have. Moreover, it is closely akin to the universal and unchanging rhythmical experiences grounded in our very bodies and senses: the heartbeat, breathing, walking, running, swimming. Therefore it is accessible to every listener always and everywhere. Yet it is also one of the greatest inventions of the human spirit, 
rigorous yet flexible, and so able to express wide-ranging thought and emotion that it was a vehicle for works of narrative and lyric poetry, even sometimes of philosophy and history, for over two thousand years in Greek and Latin.

I don't need to explain that meter to you, but rather to give some sense of how I have tried to "translate" it into English. English does not have an agreed-upon basis for a quantitative measure, and like Longfellow and others, I use the stress-based meter corresponding to it, "accentual dactylic hexameter." But the quantity of a syllable often in English accompanying the stress-contributes to the music, sometimes essentially. The dactylic foot, heavy-weak-weak, as in quantity, is predominant; but I try to maintain a fully spondaic foot, heavy-heavy, as in maintain, to balance it, and I allow few trochees, heavy-weak, as in fully, except in the final foot, where I sometimes allow a spondee, as does Homer. And I am lucky:

English, in large part uninflected and monosyllabic,

furnishes me more spondaic diction than some other tongues would.

Though prosaic, these two hexameters can suggest the resources of English and show how syllable-length can reinforce accentuation.

The long line coheres mainly because of its dactylic movement. Whenever I could, I strengthened its coherence with alliteration, which has an important place in the English poetic tradition. And the line is varied not only by the alternation of dactyls and spondees, but also by the placement of the pauses, the caesuras and diereses, for which I have tried to maintain the Homeric norms as far as possible.

Not only is the meter, with its repeated "beat," beautiful in itself, it also supports the other repetition-elements that form the texture of the epic. For music of all sorts is composed of repetitions: what we might find monotonous in prose becomes the musical substance of epic song, just as repetition of motives, themes, or entire sections animates a Bach fugue, a Debussy prelude, a Christmas carol, a popular tune. The best-known such feature in Homeric song is the noun-epithet phrase, pódas okús Achilleús, nephelegeréta Zeuis, Meneláou kudalimoio, polúmetis Odysseús. These melodious phrases please our ears each time they recur. So I have tried to give them a melodious and expressive turn in my translations, some of them traditional in English: swift-footed Achilles, the cloud-gathering god Zeus, the glorious lord Menelaos, Odysseus of many devices.

Then there are whole lines, harmonious notations of recurring circumstances, in which we take pleasure whenever we hear them, as in the well-known Êmos d'erigéneia phâne rhododáctylos eôs for the coming of day -twice in the Iliad, twenty times in the Odyssey. I wanted a line with something of that music, and found Soon as the dawn shone forth rose-fingered at earliest daybreak- less beautiful than Homer's, but good enough, perhaps, to give pleasure when repeated.

Much more common are the speech-openings: our ears delight in hearing the same resonant phrase for saying or answering used in conjunction with the same or different noun-epithet phrases. Two examples: tèn d'apameibómenos proséphe nephelegeréta Zeús, "Answering her in return spoke forth the cloud-gathering god Zeus"; tòn 
d'apameibómenos proséphe pódas okús Achilleús, "Answering him in return spoke forth swift-footed Achilles."

Other passages relate repeated actions or rituals, such as starting a voyage, coming to shore, welcoming strangers, sacrificing, eating a meal. In some cases the repetition musically reenacts the ritual itself, with variations. The refrain-like lines in the catalogue of ships, Iliad 2, and in the battle-scenes of the Iliad please by giving a musical closure to sections, like the cadences in song or symphony.

We also enjoy longer passages of verbatim repetition such as the account of Penelope weaving and unweaving a fabric to put off the suitors at three quite different places in the Odyssey, or Agamemnon's speech offering presents to Achilles as reported to him by Odysseus in book 9 of the Iliad. These too gain from the music, both because the repetition itself gives pleasure and because our musical memory deepens our grasp of the words. Sheer memorability can be an advantage; it can help a listener to perceive that Odysseus in Iliad 9 leaves out of his almost verbatim account of Agamemnon's offer four lines that were important to the king, but that would antagonize Achilles:

"Let him but yield -ungentle and ever unyielding is Hades; therefore of all of the gods is he the most hated by mortalslet him be subject to me, inasmuch as I am the more kingly; then also as I claim to be older than he in my birth date.'

Odysseus' diplomatic omission is understandabnle, but it makes us aware of the substance behind Achilles' hatred for "the man who / keeps one thing concealed in his mind while saying another." And we might miss this nuance if the music had not made it easy for us to remember the lines and notice the difference.

A word about diction. The Homeric language was never spoken; it came into being through the performances of singers who incorporated into the basic Ionic such words and grammatical forms from other dialects as fitted the dactylic music. At any given point in the history of the song or epic recitation, listeners might have found the language archaic. But I am more inclined to believe they thought of it more as a special, even timeless, language suited to song, so that later writers like the composers of the Homeric Hymns, or even Apollonios Rhodios in a literate epic, the Argonautika, could use it without feeling any great archaism. I advance this view not so much for its correctness, but as the conceptual basis for my choice of language. I have tried to write as pure a "literary" English as I could, an English that is not spoken on the street of any particular place, but that can be understood and, I hope, enjoyed wherever English is spoken, just as Homeric Greek was in the ancient world. English of this literary sort can be vivid, but it cannot have the appeal of slang or other up-to-date linguistic tricks. This too is appropriate: to experience the world of Homer at any period was to leave behind contemporary ways of encountering reality. So I do not mind if readers say that my translation smacks of Biblical or Miltonic English, but I hope it will be accessible to all Anglophones, not just Americans. 
As for proper names, like other contemporary English translators of ancient Greek classics, I try to stay close to the Greek forms. Because English has few inflections and such a hybrid vocabulary, it accommodates words of all sorts, often in the original form and with similar pronunciation. So these proper names can afford the modern reader a taste of Greek music, and I place acute accents on stressed syllables when necessary to guide the pronunciation and keep the meter flowing. For me names are especially attractive in catalogues, such as that of the sea-nymphs who join Thetis in mourning Patroklos, Iliad 18.39-49, - the names themselves sound the lament in their beauty and sweetness. Whereas some translators prefer to use English words that translate the sea-related meanings of these names, I keep the Greek forms and give meanings in the Index:

There then Glaukè was sitting, Kymódokè too, and Thaleía, Speío, Nesaíe, and ox-eyed Háliè also, and Thóë, Kýmothoé and as well Aktaïë and Lýmnoreía, Mélitè too and Iaíra, Amphíthoë too and Agaúë, Dýnamené and Pheroúsa, as well as Doto and Proto, Déxamené, Amphínomè also, and Kállianeíra, Doris and Pánopè too, and the glorious nymph Galateía, Némertés and as well Apseúdes and Kállianássa; there too Klýmenè was, Ianeíra as well, Ianássa, Maíra and Óreithuía, the fair-tressed nymph Amatheía, others of Néreus' daughters as well, in the depths of the seabrine.

Four of the translators here are evenly divided on this: Professor Ventre too uses the Greek forms, while Professors Brunet and Garcia Calvo translate them into names just as euphonious in their respective languages. So I do not wish to say that one way is better, but to explain why I chose as I did.

A few major characters are so familiar in the English literary tradition that I thought it best to keep their customary names - Achilles rather than Achilleus, Ajax rather than Aias, Helen and Priam uninflected. As for patronymics, both English tradition and my desire to stay close to Greek might have led me to use Atrides, Pelides, and others, but I thought that many modern readers do not feel the force of the father's presence in such names, so I adopted a more Germanic patronymic using son, or for the meter scion: Atreus'son, Atreus'scions, son of Laërtes, scion of Peleus. This seems especially important with the women in Iliad 1 ordinarily known as Chryseis or Chryseide and Briseis or Briseide, the only notable women in Homer called by patronymics instead of their own names like Andromache, Helen, Klytaimnestra. The translations daughter of Chryses and daughter of Briseus emphasize that their importance to their masters, Agamemnon and Achilles, lies less in themselves than in their high status as war-prizes, no mere slave-women but daughters of powerful fathers. 
I present here an extended passage to show how the meter works in my translation. The first fifty-two lines of the Iliad are surely familiar to most in this audience; the fifth line follows Prof. Ventre's view rather than my own published work:

Sing now, goddess, the wrath of Achilles the scion of Peleus, ruinous rage which brought the Achaians uncounted afflictions; many the powerful souls it sent to the dwelling of Hades, those of the heroes, and spoil for the dogs it made of their bodies, feasts for the carrion birds, and the purpose of Zeus was accomplished sing from the time when first stood hostile, starting the conflict, Atreus' scion, the lord of the people, and noble Achilles.

Which of the gods brought strife to the two men, set them to fighting? It was the offspring of Leto and Zeus; for enraged at the king, he roused in the army a baneful disease, and the people were slaughtered, all on account of his priest, whom Atreus' scion dishonored, Chryses. For he had arrived at the swift ships of the Achaians, seeking to free his daughter and bringing a measureless ransom, bearing in hand bay-garlands of great far-shooting Apollo wound on a gold-wrought staff, and he pled with them, all the Achaians, but above all the two scions of Atreus, marshals of people: "Atreus' scions as well as the rest, you well-greaved Achaians, now may the gods who dwell in Olympian palaces let you ransack the city of Priam and safely arrive in your homeland; but as for my dear child, set her free and accept this ransom, showing respect for the scion of Zeus, far-shooting Apollo.” Thereat all of the other Achaians were shouting approval, saying to honor the priest and accept the magnificent ransom; yet this pleased not the spirit of Atreus' son Agamemnon; roughly he sent him away, and he laid a strong order upon him: "Old man, never may I by the hollow ships come upon you, either now lingering on, or returning again in the future, lest no help to protect you the god's staff prove, nor his garland. Her I will not give freedom; before, old age will assail her there in our house in Argos and far from the land of her fathers, where she will weave at a loom and will share my bed and affection. Go now, do not provoke me, that you might go the more safely." So he spoke, and the old man feared, and obeyed what he said and silently went by the shore of the deep sea rumbling and booming. Loudly the old man, once he had gone to a distance, addressed his prayer to the lordly Apollo, whom Leto of beautiful hair bore: "Hear me, god of the silvery bow, who stride around Chrysè and around Killa the sacred, and Tenedos mightily govern, 
Smintheus, if a delectable temple I ever have built you, or if savory fat thigh-pieces I ever have burnt you either of bulls or of goats, then bring this boon to fulfillment: make those Dánaäns pay for my tears by shooting your arrows." So he spoke as he prayed; he was heard by Phoibos Apollo.

Down from the peaks of Olympos he came, enraged in his spirit, holding his bow on his shoulders as well as a close-covered quiver. Arrows were clattering loud on his shoulders as he in his anger started impetuous motion, and like night he was advancing. Then well away from the ships he sat, and an arrow he let fly; dreadfully out of the silvery bow then started the clangor.

It was the mules and the swift-paced dogs that first he assaulted, but then straight at the men themselves a sharp arrow he shot and struck: and the pyres close-crowded were always ablaze with the corpses.

Thanks again to professor Brunet and the other organizers of the conference for inciting me to speak about this important topic to an audience I would otherwise never had the privilege of addressing.

$\frac{\text { Rodney MERRILL }}{\text { rodmerrill@earthlink.net }}$

\section{Bibliographical Note}

Since my contribution is largely a personal account of the way I came to translate Homer, and of how I pursued that ambition, a full scholarly apparatus is not appropriate. I list here only a few works whose importance for my approach is expressed or implied in my presentation. Fuller bibliographical lists are available elsewhere in this collection.

Apollonios rhodios, The Argonautika, trans. R. Merrill, with an introduction by the translator, , p. 1-19CreateSpace Independent Publishing Platform, 2012.

M. ARnold, On Translating Homer, London 1861.

S.G. DAITZ, reader, The Iliad of Homer in Ancient Greek, Madison, CT, Audioforum, 1992 (see http://rhapsodes.fll.vt.edu/iliad1.htm, Deatz's reading of Iliad 1.1-52).

M.W. Edwards, Sound, Sense, and Rhythm: Listening to Greek and Latin Poetry, Princeton 2002.

Homer, The Iliad, trans. R. MerriLl, with an introduction by the translator, "Singing the Iliad", p. 1-22, Ann Harbor 2002. 
"The Homeric Hymn to Apollo", trans. R. MerriLl, in A Californian Hymn to Homer, ed. T. Pepper, p. 211-234, Center for Hellenic Studies, Harvard University Press, Cambridge MA and London 2010.

Homer, The Odyssey, trans. R. Merrill, with introductions by the translator and T.R. WALSH: "The Odyssey: The Tradition, the Singer, the Performance", p. 1-53, and "Translating Homeric Song", p. 54-73, Ann Arbor 2002. The second of these is the fullest published account of my reasons for translating Homeric epic intro English dactylic-hexameter verse.

A.B. Lord, The Singer of Tales, new edition by S. Mitchell and G. NAGY, Cambridge MA 2000.

M. Parry, The Making or Homeric Verse: The Collected Papers of Milman Parry, ed. Adam Parry, Oxford 1971.

R. MerRILL, Translating the Odyssey, http://home.earthlink.net/-merrill_odyssey.

G. NagY, The Best of the Achaeans: Concepts of the Hero in Archaic Greek Poetry, revised edition, Baltimore 1999.

G. Nagy, Poetry as Performance: Homer and Beyond, Cambridge 1996.

M. PARrY, The Making of Homeric Verse: The Collected Papers of Milman Parry, ed. A. Parry, Oxford 1971.

Plato, Ion, trans. L. Cooper, in The Collected Dialogues of Plato, ed. E. Hamilton and H. CAIRNS, New York 1961, p. 216-228.

M.L. West, Ancient Greek Music, Oxford 1992. 